\title{
Potansiyel Doğal Bir Antioksidan Illaç Olarak Goji Meyvelerinin Moleküler Mekanizmaları, Biyolojik ve Farmakolojik Özellikleri*
}

\author{
Molecular Mechanisms, Biological and Pharmacological Properties of Goji Berries as a Potential Natural \\ Antioxidant Medicine \\ Sevgi Gezici
}

'Doç. Dr. Gaziantep Üniversitesi Tıp Fakültesi, Temel Tıp Bilimleri, Tıbbi Biyoloji AD., https://orcid.org/0000-0002-4856-0221

öz

Diyet ile alınan gıdalarda bulunan fonksiyonel veya biyoaktif bileşenler, metabolizmada pek çok süreci ve moleküler sinyal yolağını modüle etme yeteneğine sahip biyomoleküllerdir. Son yıllarda, gıda ve ilaç olarak kullanım potansiyelleri kanıtlanmış, zengin biyolojik aktivitelere ve farmakolojik özelliklere sahip pek çok bitkisel doğal ürün tanımlanmıştır. Sentetik antioksidanların olası toksik etkilerinin rapor edilmesiyle birlikte, doğal antioksidan bileşikler içeren tıbbi ve aromatik bitkilere yönelik araştırmalar hız kazanmıştır. 'Gojiberry', 'Goji meyveleri', 'wolfberry', 'kurt üzümü' veya 'süper meyve' olarak bilinen meyveler Lycium chinense Mill., L. barbarum L. ve L. ruthenicum Murr. bitki türlerinin meyveleridir. Polisakkaritler, flavonoidler, fenolikler, karotenoidler, vitaminler, yağ asitleri, betain ve peptidoglikanlar gibi çeşitli fonksiyonel bileşenlerin varlığının tanımlandığı goji meyveleri doğal antioksidan kaynağıdır. Zengin biyoaktif bileşenleri sayesinde; yaşlanma karşıtı, yara iyileştirici, antikanser, nöroprotektif, sitoprotektif, anti-diyabetik, antiinflamatuvar ve immün sistem güçlendirici olarak pek çok biyolojik aktiviteye sahiptir. Goji meyvelerinin, tıp alanında özellikle glokom, böbrek yetmezliği, karaciğer hasarı, kanser, hepatit, hiperlipidemi, tromboz, diyabet ve kısırlık tedavisinde kullanım potansiyeline sahip olduğu rapor edilmiştir. Güçlü antioksidan kapasitesi ve zengin fitokimyasal bileşimi ile gerek ilaç sanayisinin gerekse bilim camiasının dikkatini çeken, Goji meyvelerinin fitokimyasal içerikleri, nutrasötik değeri, geleneksel kullanımları, moleküler etki mekanizmaları, etkili oldukları sinyal yolakları ile farmakolojik özellikleri bu makalenin konusunu oluşturmuştur.

Anahtar Kelimeler: Biyoaktif bileşikler, Farmakolojik özellikler, Goji meyveleri, Gen-hastalık, Moleküler mekanizma, Şifalı bitki

\section{ABSTRACT}

Functional or bioactive components in dietary foods are biomolecules that have the ability to modulate many processes and molecular signaling pathways in metabolism. In recent years, many herbal natural products, having rich biological activities and pharmacological properties have been identified that have proven potential for use as food and medicine. Due to the reporting of possible toxicity of synthetic antioxidants, research on medicinal and aromatic plants containing natural antioxidant compounds has gained momentum. Berries known as 'gojiberry', 'goji berries', 'wolfberry', 'wolfberry' or 'superfruit' are the fruits of Lycium chinense Mill., L. barbarum L., and L. ruthenicum Murr. Goji berries are a natural source of antioxidants, with the presence of various functional components such as polysaccharides, flavonoids, phenolics, carotenoids, vitamins, fatty acids, betaine and peptidoglycans. Thanks to its rich bioactive components; it has many biological activities as anti-aging, wound healing, anticancer, neuroprotective, cytoprotective, anti-diabetic, anti-inflammatory and immune system-boosting. It has been reported that goji berries have the potential to be used in the medical field, especially in the treatment of glaucoma, kidney failure, liver damage, cancer, hepatitis, hyperlipidemia, thrombosis, diabetes and infertility. The phytochemical contents, nutraceutical value, traditional uses, molecular mechanisms of action, signaling pathways and pharmacological properties of Goji berries, which attract the attention of both the pharmaceutical industry and the scientific community with their strong antioxidant capacity and rich phytochemical composition have been formed the subject of this article.

Keywords: Bioactive compounds, Pharmacological properties, Goji berries, Gene-disease, Molecular mechanism, Medicinal plant.

${ }^{*}$ Mersin Üniversitesi Tıp Fakültesi Lokman Hekim Tıp Tarihi ve Folklorik Tıp Dergisi, 2022; 12 (1): 67-76

DOI: $10.31020 /$ mutftd.1009225

e-ISSN: 1309-8004, ISSN 1309-761X

Geliş Tarihi - Received: 13 Ekim 2021; Kabul Tarihi - Accepted: 04 Ocak 2022

iletişim - Correspondence Author: Sevgi Gezici <sevgigezici@gantep.edu.tr> 


\section{Giriş}

Tıbbi bitkiler ve bitkilerden elde edilen sekonder bileşikler sahip oldukları biyolojik ve farmakolojik özellikleri sayesinde vücudun savunma sistemine ciddi ölçüde katkı sağlamaktadır. Bazı sentetik antioksidanlar için kanserojen özellikler gösterdikleri yapılan araştırmalarla ortaya konulduğundan, tıbbi bitkilerden elde edilen doğal antioksidanlar, insan vücudunda oksidatif hasarın azaltmasına ve oksidatif bozulmayı önleyerek gıda kalitesinin korumasına yardımcı doğal ürünler olarak dikkat çekmektedir. Bu bağlamda; beslenme ve diyet ile alınan, antioksidan kapasiteye sahip doğal ürünler; hücrelerde meydana gelen oksidatif hasarı azaltmaya yönelik koruyucu ajanlar olarak önemli rol oynamaktadır. ${ }^{1-4}$

Goji berry, nutrasötik olarak kullanılabilen veya insan sağlığını korumak için doğrudan diyette alınan önemli bir antioksidandır. Goji meyveleri (Lycium meyveleri), genellikle Asya'nın kuzeybatı bölgelerinde doğal olarak yayılış gösteren ve Solanaceae familyasına ait olan Lycium chinense Mill., L. barbarum L. ve L. ruthenicum Murr. bitki türlerinin meyveleridir. 'Gojiberry', 'Goji meyveleri', 'wolfberry', 'kurt üzümü' veya 'süper meyve' olarak bilinen bu meyveler; $1-2 \mathrm{~cm}$ uzunluğunda, parlak turuncu-kırmızı renkli, tatı ve keskin aromaya sahiptir. ${ }^{5-7}$ (Şekil 1).

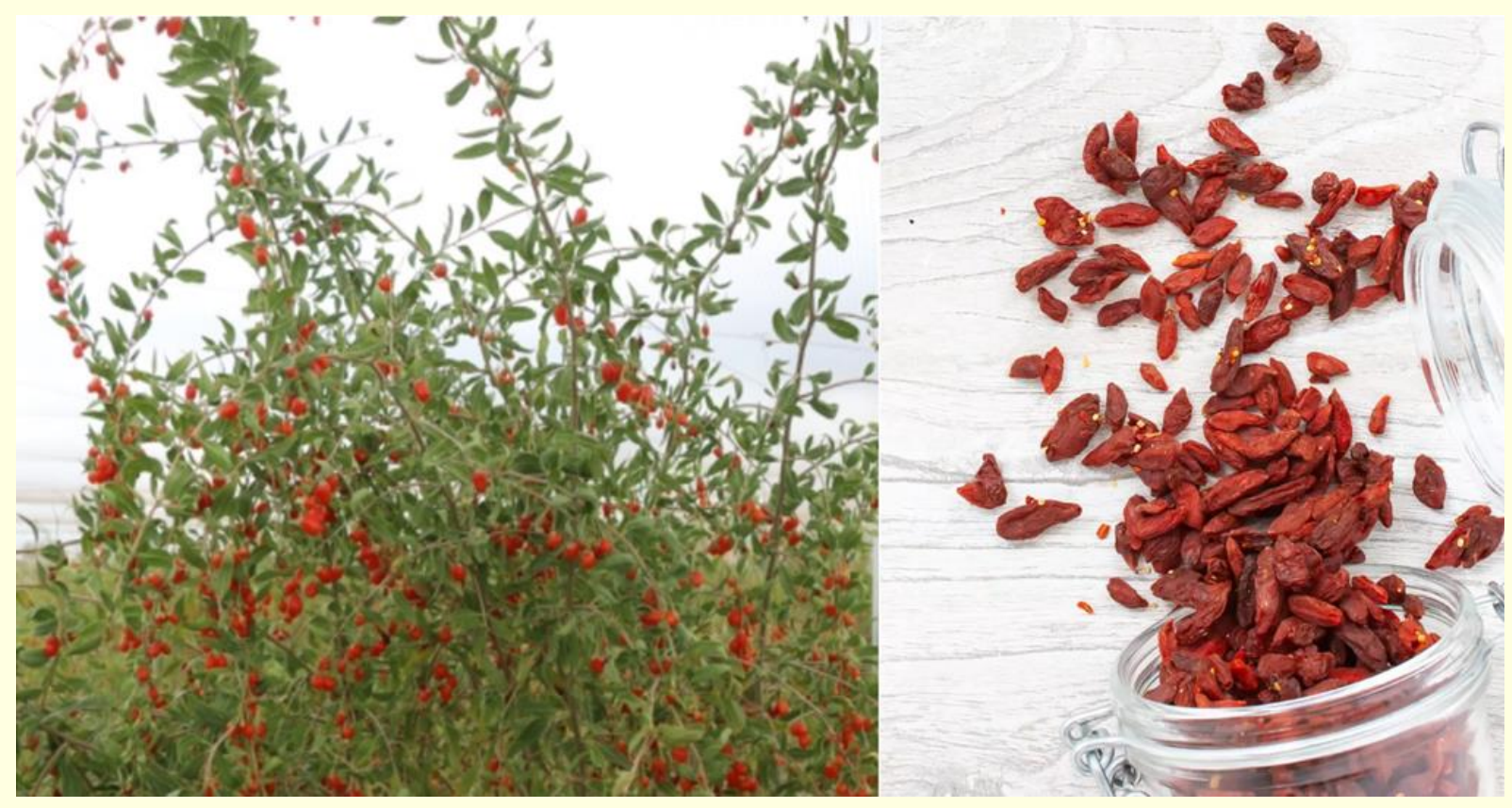

Şekil 1. Goji meyvelerinin (Lycium meyveleri, kurt üzümü veya süper meyve) genel görünümü

Geleneksel olarak, kurutulmuş meyve veya bitkisel çay olarak tüketilmelerinin yanı sıra; tentür, şarap ve meyve suyu yapımında da kullanılmaktadır. ${ }^{8,9}$ Tıp ve eczacılık alanında; yaşlanma karşıtı, yara iyileştirici, antikanser, nöroprotektif, sitoprotektif, anti-diyabetik, anti-inflamatuvar ve immün sistem güçlendirici özellikleri sayesinde özellikle glokom, böbrek yetmezliği, karaciğer hasarı, kanser, hepatit, hiperlipidemi, tromboz, diyabet ve kısırlık tedavisinde kullanım potansiyeline sahip olduğu rapor edilmiştir. ${ }^{10-12}$ Ayrıca, geleneksel Çin tıbbında retinopatili hastalarda oksidasyonu azaltmaya yardımcı olduğu gösterilmiştir. ${ }^{13}$ Polisakkaritler, flavonoidler, fenolikler, karotenoidler (beta-karoten, lutein, likopen, zeaksantin, zeaksantin dipalmitat), vitaminler (askorbik asit glukopiranozil askorbik asit ve tokoferol), yağ asitleri, betain ve peptidoglikanlar gibi çeşitli fonksiyonel bileşenlerin varlığının, Lycium meyvelerinin zengin biyolojik ve farmakolojik özelliklerinden sorumlu olduğu düşünülmektedir. ${ }^{9,14}$

Goji meyveleri, Avrupa'nın yanı sıra birçok Asya ülkesinde de yavaş yavaş fonksiyonel bir gıda olarak kabul edilmektedir. Ayrıca batı ülkelerinde sağııkı gıda olarak 'Gojiberry' ticari ismiyle pazarlanmaktadırlar. Goji meyveleri, sağlık üzerindeki olumlu etkileri nedeniyle son zamanlarda Kuzey Amerika ve Avrupa ülkelerinde 
"süper meyve" olarak artan bir popülerlik kazanmıştır. Lycium meyveleri, zengin tıbbi özellikleri, kimyasal bileşimleri, biyolojik ve farmakolojik aktiviteleri nedeniyle yüzlerce yıldır beslenmede önemli bir gıda takviyesi ve farklı bitkisel formülasyonlar olarak tüketilmektedir. ${ }^{5,6,15-17}$ Bu kapsamda, zengin fitokimyasal bileşimi ve güçlü antioksidan kapasitesi ile gerek ilaç sanayisinin gerekse bilim camiasının dikkatini çeken, 'Goji meyveleri' veya 'kurt üzümü' bu derlemenin konusunu oluşturmuştur. Bilimsel veriler ışığında hazırlanan bu yazıda, goji meyvelerinin; botanik özellikleri, biyoaktif bileşenleri, nutrasötik değeri, geleneksel kullanımları, moleküler etki mekanizmaları, etkili oldukları sinyal yolakları, biyolojik ve farmakolojik aktiviteleri derlenmiştir.

\section{Goji Meyvelerinin Biyoaktif Kompozisyonu ve Nutrasötik Özellikleri}

Fonksiyonel veya biyoaktif bileşenler, çoğunlukla gıdalarda bulunan ve insan metabolizmasında sağlığa yararları ve refahın teşviki ile sonuçlanan bir veya daha fazla metabolik süreci veya yolu modüle etme yeteneğine sahip olan fitokimyasalları içeren biyomoleküllerdir. ${ }^{1-3,15}$ Biyolojik olarak aktif pek çok bileşen ihtiva eden Goji meyveleri, mükemmel bir fonksiyonel gıda kaynağıdır. Genel olarak, meyvenin \%46'sı karbonhidrat, \%16'sı diyet lifleri, \%13'ü protein ve yaklaşık \%2'si yağlardan oluşmaktadır. Makro besinlerin yanı sıra; riboflavin, tiamin, nikotinik asit gibi vitaminler; bakır, manganez, magnezyum ve selenyum gibi mineraller yönünden de zengindir. İhtiva ettiği makro ve mikro besinler sayesinde güçlü biyolojik aktiviteler sergileyen Lycium meyveleri, insan sağ|ı̆̆ı açısından oldukça önemli bir besin kaynağıdır. ${ }^{6-8}$

Goji meyvelerinde bulunan en önemli biyoaktif bileşenler; polisakkaritler, karotenoidler, flavonoidler ve fenoliklerdir. Bu gruplardan; suda çözünebilir özellikte olan polisakkaritler (arabinoz, galaktoz, glikoz, ramnoz, mannoz, ksiloz ve galakturonik asit), kuru meyvenin yaklaşık \%5-8'ini oluşturmaktadır. Diğer önemli bir grup olan karotenoidler ise yağda çözünür özellikte olup; kuru meyve ağırlığının $\% 0.03$ ile \%0.5'ini oluşturmakta ve meyvenin karakteristik olarak parlaklığından sorumludur. ${ }^{6,14,18}$ Dipalmitin zeaksantin formundaki zeaksantin, Lycium meyvelerinde en yaygın olarak bulunan karetenoid çeşididir. Meyvenin olgunlaşmasına bağlı olarak, zeaksantin içeriği toplam karotenoid içeriğinin \%78'ine ulaşabilmektedir. Bu nedenle, goji meyveleri dipalmitin zeaksantin için doğal bir kaynaktır. Zeaksantin palmitat (phasalien) ise, toplam karotenoid içeriğinin yaklaşık \%31-56'sını içermektedir. Bunun yanı sıra, beta-karoten (35.9 $\mathrm{\mu g} / \mathrm{g})$, kriptoksantin ve neoksantin $(72.1 \mu \mathrm{g} / \mathrm{g})$ fraksiyonları da goji meyve özütlerinde tespit edilmiştir. Flavonoidler ve fenolik asitler goji meyvelerinde bulunan diğer önemli biyoaktif bileşenlerdir. Kafeik asit $(3.73 \mu \mathrm{g} / \mathrm{g})$, kafeoilkinik asit $(0.34 \mu \mathrm{g} / \mathrm{g})$, klorojenik asit $(12.4 \mu \mathrm{g} / \mathrm{g})$, p-kumarik asit $(6.06 \mu \mathrm{g} / \mathrm{g})$, kersetin-diglukozit (66.0). $\mu \mathrm{g} / \mathrm{g})$, kaempferol-3-O-rutinoside $(11.3 \mu \mathrm{g} / \mathrm{g})$ ve rutin $(42.0 \mu \mathrm{g} / \mathrm{g})$ Lycium meyvelerinde bulunan ve yüksek oranda antioksidan kapasiteye sahip bazı fenolik bileşiklerdir. ${ }^{6,714}$ Goji meyvelerinde bulunan bazı kimyasal komponentler ve besin içerikleri Tablo 1'de özetlenmiştir.

Tablo 1. Goji meyvelerinin nutrasötik değeri ve bazı önemli bileşenleri 6,7,14

\begin{tabular}{ll}
\hline Kompozisyon & Oranı (\%) \\
\hline Karbonhidrat & $\% 46$ \\
Diyet lif & $\% 16$ \\
Protein & $\% 13$ \\
Nem & $\% 10.3$ \\
Basit protein & $\% 8.9$ \\
Yağ & $\% 2$ \\
Oleik asit & $\% 21.7$ \\
Palmitik asit & $\% 8.2$ \\
Stearik asit & $\% 2.9$ \\
Araşidik asit & $\% 1.8$ \\
Toplam fenol & $\% 3.4$ \\
\hline
\end{tabular}




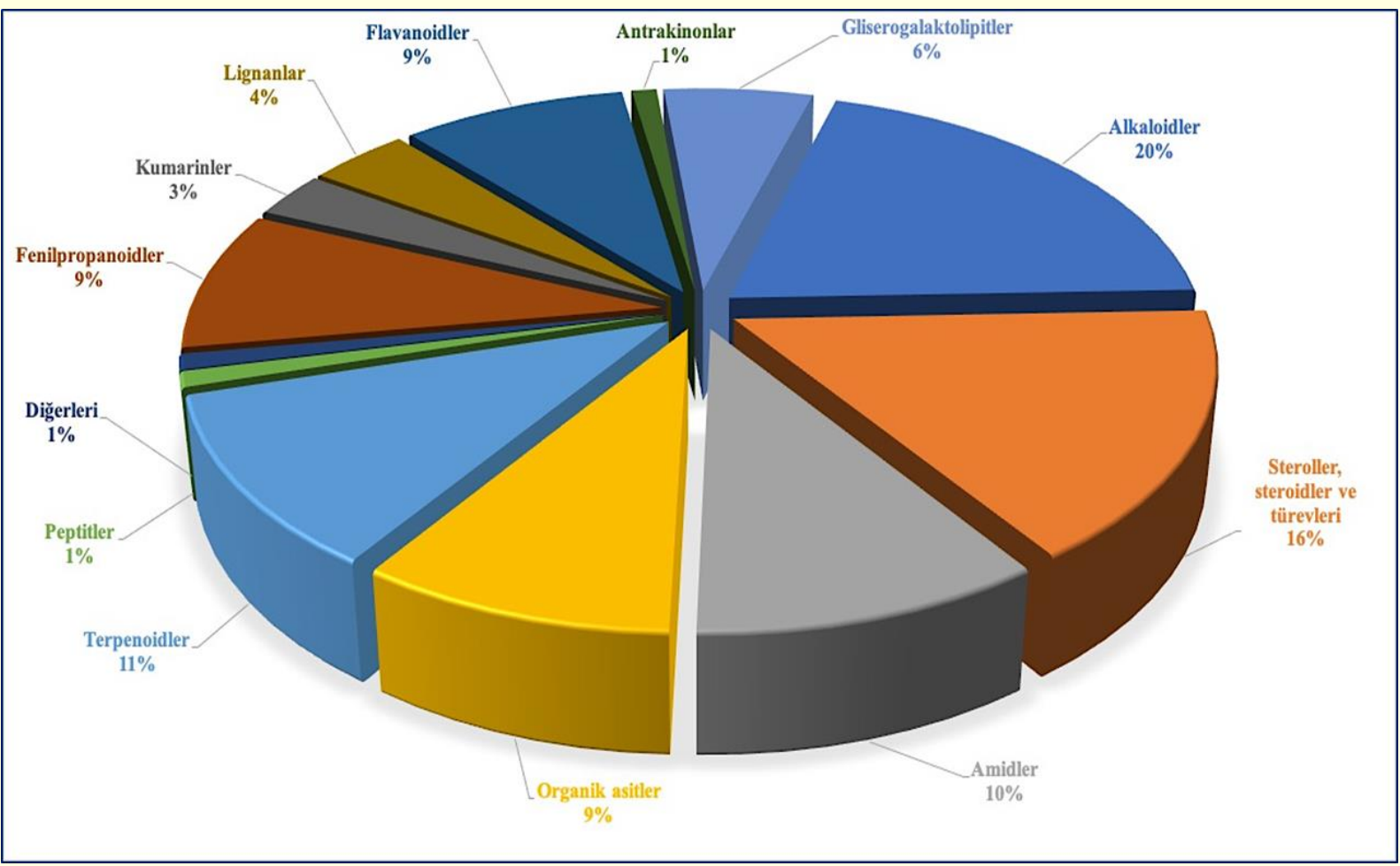

Şekil 2. Lycium cinsinin ihtiva ettiği farklı fitokimyasalların dağııımı 7,15

Goji meyvelerinde en temel bulunan bileşen polisakkaritler olmakla birlikte; polisakkaritlerin yanı sıra yaklaşık 355'den fazla farklı bileşik tanımlanmıştır. Bunlar; gliserogalaktolipitler, fenilpropanoidler, kumarinler, liganlar, flavonoidler, amidler, alkaloidler, antrakinonlar, organik asitler, terpenoidler, steroller, peptitler, steroidler ve bunların türevleri olmak üzere genel olarak kategorize edilebilmektedir. ${ }^{5,7,15}$ Lycium cinsinin intiva ettiği farklı komponentlerin dağılımı Şekil 2' de verilmiştir.

\section{Goji Meyvelerinin Moleküler Mekanizmaları ve İlişkili Olduğu Sinyal Yolakları}

Goji meyveleri ihtiva ettiği eşsiz polisakkaritleri sayesinde Meyvelerin Kralı 'Kings of the Berries' olarak nitelendirilmekte ve pek çok hastalık gelişiminin engellenmesinde, hastalık ile ilişkili genler ve moleküler sinyal yolaklarında etkin rol oynamaktadır. ${ }^{6,11}$ Lycium meyvelerinin ihtiva ettikleri polisakkaritlerin moleküler olarak etkili oldukları sinyal yolakları, etkileşimde oldukları genler ve genlerin genom sıklıkları Tablo 2'de verilmiştir. Lycium polisakkaritlerinin ilişkili olduğu genler, moleküler sinyal yolları ve hastalıklar Comparative Toxicogenomics Database, CTD'den alınmış ve Tabloda veriler sunulurken, doğrulanmış $p$ değeri $<0.01$ olanlar alınmıştır. ${ }^{19}$

Lycium polisakkaritlerinin en sık ilişkili olduğu genler; katalaz (CAT), glutatyon peroksidaz-1 (GPX1), süperoksit dismutaz 1 ve 2 (SOD1 ve SOD2), tümör nekröz faktör (TNF), RELA proto-onkogen-NF-kB alt ünitesi (RELA) ve interselüler adezyon molekülü (ICAM1) olarak belirlenmiştir (Tablo 2). Goji meyvelerinde bulunan polisakkaritler ilişkili olduğu bu genlerden; CAT, GPX1, SOD1 ve SOD2'nin metabolizmadaki ekspresyon seviyelerinin artışına neden olurken; ICAM1, RELA ve TNF genlerinin ise metabolizmadaki ekspresyon seviyelerinin azalmasına neden olduğu ortaya konulmuştur. ${ }^{11,20-25}$ 
Tablo 2. Goji meyvelerindeki polisakkaritlerin ilişkili olduğu hastalıklar, genler ve moleküler sinyal yolları

\begin{tabular}{|c|c|c|c|c|}
\hline $\begin{array}{l}\text { iliş̧kili Olduğu Hastalıklar ve } \\
\text { Moleküler Sinyal Yolları }\end{array}$ & P-değeri & $\begin{array}{l}\text { Doğrulanmış } \\
\text { P-değeri }\end{array}$ & ilişkili Olduğu Genler & Genom sıklığı \\
\hline $\begin{array}{lll}\text { Reaktif oksijen } & \text { türlerinin } \\
\text { detoksifikasyonu } & \end{array}$ & $1,60 \mathrm{E}-11$ & 2,97E-09 & CAT, GPX1, SOD1, SOD2 & 38/44381 gen: $\% 0,09$ \\
\hline Amyotrofik lateral skleroz (ALS) & $5,40 \mathrm{E}-11$ & $1,00 \mathrm{E}-08$ & CAT, GPX1, SOD1, TNF & 51/44381 gen: \%0,11 \\
\hline $\begin{array}{l}\text { Stres durumuna karşı hücresel } \\
\text { cevaplar }\end{array}$ & 2,19E-09 & $4,07 E-07$ & CAT, GPX1, RELA, SOD1, SOD2 & 451/44381 gen: $\% 1,02$ \\
\hline $\begin{array}{l}\text { Longevity düzenleyici sinyal yolu - } \\
\text { multiple türler }\end{array}$ & $9,05 E-08$ & $1,68 \mathrm{E}-05$ & CAT, SOD1, SOD2 & 62/44381 gen: $\% 0,14$ \\
\hline Peroksizom & $2,20 \mathrm{E}-07$ & $4,08 \mathrm{E}-05$ & CAT, SOD1, SOD2 & 83/44381 gen: \%0,19 \\
\hline Longevity düzenleyici sinyal yolu & $2,71 \mathrm{E}-07$ & $5,05 \mathrm{E}-05$ & CAT, RELA, SOD2 & 89/44381 gen: $\% 0,20$ \\
\hline NF-kappa B sinyal yolu & $3,20 \mathrm{E}-07$ & $5,95 \mathrm{E}-05$ & ICAM1, RELA, TNF & 94/44381 gen: \%0,21 \\
\hline $\begin{array}{l}\text { Diyabetik komplikasyonlarda AGE- } \\
\text { RAGE sinyal yolu }\end{array}$ & $3,74 \mathrm{E}-07$ & $6,96 \mathrm{E}-05$ & ICAM1, RELA, TNF & 99/44381 gen: \%0,22 \\
\hline $\begin{array}{l}\text { Tümör nekröz faktör (TNF) sinyal } \\
\text { yolu }\end{array}$ & $4,87 \mathrm{E}-07$ & $9,06 \mathrm{E}-05$ & ICAM1, RELA, TNF & 108/44381 gen: $\% 0,24$ \\
\hline Pürin katabolizması & $9,59 \mathrm{E}-07$ & $1,78 \mathrm{E}-04$ & CAT, GPX1 & 10/44381 gen: $\% 0,02$ \\
\hline Fluid shear stres ve ateroskleroz & $1,11 \mathrm{E}-06$ & $2,07 E-04$ & ICAM1, RELA, TNF & $142 / 44381$ gen: $\% 0,32$ \\
\hline Influenza A & $2,01 E-06$ & $3,75 \mathrm{E}-04$ & ICAM1, RELA, TNF & 173/44381 gen: $\% 0,39$ \\
\hline Huntington hastalığı & $2,80 E-06$ & $5,20 \mathrm{E}-04$ & GPX1, SOD1, SOD2 & 193/44381 gen: $\% 0,43$ \\
\hline $\begin{array}{l}\text { İnsan T lenfotropik virüsü-1 (HTLV- } \\
\text { 1) enfeksiyonu }\end{array}$ & $6,53 \mathrm{E}-06$ & 0,00121 & ICAM1, RELA, TNF & 256/44381 gen: $\% 0,58$ \\
\hline Antifolat dirençi & $9,89 \mathrm{E}-06$ & 0,00184 & RELA, TNF & 31/44381 gen: $\% 0,07$ \\
\hline Afrika tripanozomisi & 1,19E-05 & 0,00222 & ICAM1, TNF & 34/44381 gen: $\% 0,08$ \\
\hline Pürin metabolizması & $1,19 \mathrm{E}-05$ & 0,00222 & CAT, GPX1 & $34 / 44381$ gen: $\% 0,08$ \\
\hline
\end{tabular}

Tablo'da sunulan veriler, Comparative Toxicogenomics Database (CTD)'den alınmıştır.

\section{Goji Meyvelerinin Farmakolojik Özellikleri}

Goji meyveleri, "besin açısından zengin" ve "güçlü antioksidan" özellikleri nedeniyle insanlar tarafından son derece avantajlı bir "süper gıda" olarak kabul edilmiş ve yıllar içerisinde popüler hale gelmiştir. Goji meyvelerinin zengin karotenoid içeriği sayesinde görme, retinopati ve maküler dejenerasyon üzerindeki olumlu pek çok araştırmanın konusu olmuştur. İnsan sağlığı üzerindeki olumlu etkileri son yıllarda en sık tüketilen dut tipi meyveler; goji (Lycium barbarum), chia (Salvia hispanica), açaí (Euterpe oleracea Martius), hünnap (Ziziphus jujuba), nar (Punica granatum) ve mangosteen (Garcinia mangostana)'dir. Bütün bu meyveler besin açısından oldukça zengin olup, intiva ettikleri fitosteroller, tekli doymamış yağlar, antioksidanlar, esansiyel amino asitler, eser mineraller, diyet lifleri, yağda ve suda çözünen vitaminler sayesinde bağışıklık sistemini güçlendirici özelliğe sahiptir. $6,18,26$

Özellikle goji meyvelerinde bulunan ve oldukça kıymetli bir fonksiyonel bileşen olan polisakkaritler, geleneksel Çin tıbbında tedavi amaçlı ve ayrıca gıda olarak yıllardır kullanılmaktadır. ${ }^{13,17}$ Günümüzde goji meyveleri, sadece Çin'de değil dünya çapında meyve suyu ve bitkisel çay dahil olmak üzere çeşitli formlarda sağııkı bir gıda takviyesi olarak kullanılmaktadır. Kurt üzümü olarak da bilinen goji meyveleri ve bu meyvelerden elde edilen ürünler sağlık alanında özellikle diyabet ${ }^{8,24}$, hiperlipidemi ${ }^{24,32,35}$, kanser gelişiminin engellenmesinde ${ }^{12,28,29,34}$, bağışıklık bozukluklarında ${ }^{29,33}$, hepatit ${ }^{27,28,30}$, sinir sistemine karşı koruyucu ${ }^{31,36}$, tromboz ve kısırlık problemlerinde ${ }^{26}$ ve ayrıca görme ${ }^{13}$, böbrek ve karaciğer fonksiyonlarının yerine getirilmesinde ${ }^{27,30}$ önemli kullanım alanlarına sahiptir. Goji berry meyvelerinin sahip oldukları kullanım alanları genel olarak aşağıda maddeler halinde özetlenmiş ve Şekil 3'de şematize edilmiştir. 


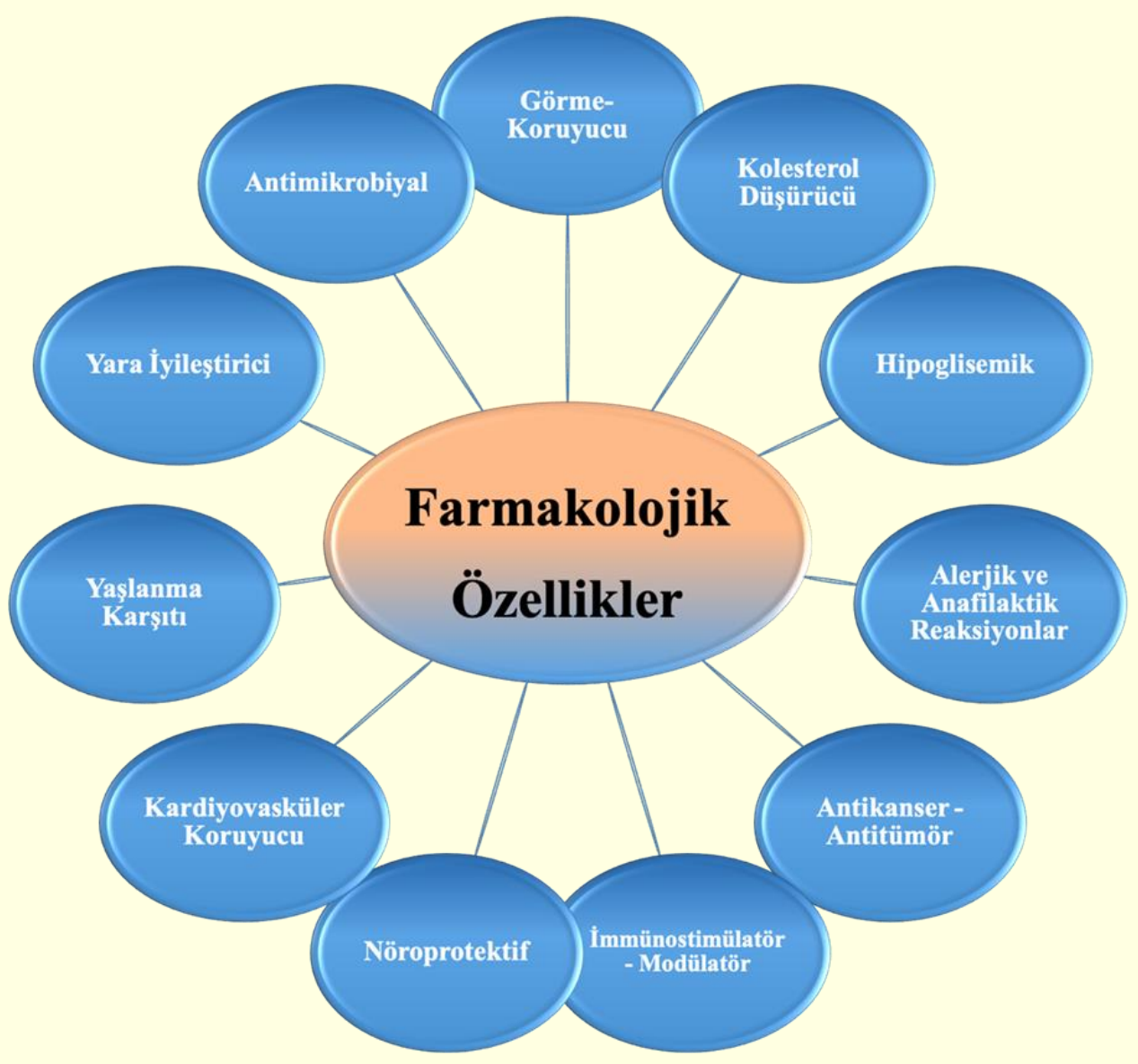

Şekil 3. Goji meyvelerinin genel olarak farmakolojik özellikleri

- Antioksidan kapasiteleri sayesinde metabolik reaksiyonlar sonucunda hücrelerde meydana gelen serbest radikallerin zararlı etkilerinin ve DNA hasarlarının ortadan kaldırılmasında etkilidir. ${ }^{6,15}$

- Göz ile ilgili koruyucu etkilere sahip olup, genel olarak glokom tedavisinde ve retina koruyucu olarak kullanılmaktadır. ${ }^{13,38}$

- Kolesterol seviyesini düşürerek, kan damarlarında sertleşmeyi ve plak oluşunu engelleyicidir. ${ }^{8}$

- Hipoglisemik özelliğe sahip olan meyveler kan şekerini dengeleyici olarak etki göstermektedir. 8,24,35

- Nöroprotektif etkiler gösteren goji meyveleri, nöronları hasara karşı koruyucudur. . $^{31,36}$

- İmmünostimülatör ve modülatör olarak bağışıklık sistemini güçlendirici özelliktedir. ${ }^{29,33}$

- Alerjik ve anafilaktik reaksiyonların engellenmesinde etkilidir.

- İçerdiği etken bileşikler sayesinde yaşlanma karşıtı olarak anti-aging teknolojisinde kullanılmaktadır. ${ }^{37}$

- Kan basıncını dengeleyerek kalp damar dayanıklılı̆ını artırdığından dolayı kardiyovasküler koruyucu özelliktedir. ${ }^{32,35}$

- Karaciğer rahatsızlıklarına karşı hepatoprotektif aktivite göstermektedir. ${ }^{27,28,30}$

- Hücrelerde meydana gelen kontrolsüz hücre bölünmelerine karşı antikanser ve antitümör etkilere sahiptir. ${ }^{12,14,28,29,34}$

Kurt üzümünün retina hücrelerinde meydana gelen rejenerasyona karşı retinoprotektif kapasiteye sahip olduğu hem insan hem de hayvan çalışmaları ile ortaya konulmuştur. ${ }^{6,13,38}$ Ayrıca, Lycium meyvelerinde yüksek oranda bulunan polisakkaritlerin ve proteoglikanların, görme fonksiyonlarını iyileştirici özellikte 
oldukları ve ayrıca oküler nöroprotektif etkiler gösterdikleri bildirilmiştir. ${ }^{14,31,36}$ Ayrıca, neredeyse total karatenoid içeriğinin \%60'ını oluşturan zeaksantin sayesinde, goji meyveleri spesifik karotenoid profili ihtiva etmektedir. ${ }^{15}$ Bilindiği üzere karotenoidler, birçok meyve ve sebzenin sarı, kırmızı ve turuncu renkte olmasından sorumlu ana doğal pigmentlerdir. Bu pigmentler, pro-vitamin A'nın antioksidan aktivitesi de dahil olmak üzere birçok biyolojik etkiye sahiptirler. ${ }^{24,27}$ Chu ve arkadaşları, Lycium polisakkaritlerinin kısmi optik sinir transeksiyonu (PONT) modelinde Lycium polisakkaritlerinin $(1 \mathrm{mg} / \mathrm{kg})$ sıçanların retina fonksiyonundaki lokalize değişikliklerinin etkilerini araştıran bir hayvan çalışması gerçekleştirmişlerdir. Yapılan çalışma ile, Lycium polisakkaritlerinin sıçanlarda retinadan gelen sinyallarin düzenlenmesine ve retina fonksiyonlarının düzelmesine yardımcı olduğu ortaya konulmuştur. ${ }^{38}$ Zhu ve arkadaşları tarafından gerçekleştirilen başka bir çalışmada ise, Lycium polisakkaritlerinin N-metil-N-nitrosourea ile indüklenen sıçan fotoreseptör hücre apoptozunu inhibe ettiği bildirilmiştir. Ek olarak, polisakkaritlerin kaspaz ve PARP ekspresyonlarını düzenleyerek retinal yapının korunmasında da etkili olduğu gösterilmiştir. ${ }^{39}$ Yapılan başka bir çalışmada ise, gojiberry'nin zeaksantin ve luteolin karotenoid metabolik genlerinin ekspresyon seviyesini artırdığı ve ayrıca diyabetik farelerin retinasındaki mitokondri biyogenezini iyileştirdiği gösterilmiştir. Bu zeaksantin ve luteolin metabolize eden genlerin ekspresyonunun inhibe edilmesinin, retinopati riskini artıran hiperglisemiye neden olabileceği de öne sürülmüştür. ${ }^{40}$

Sağlıklı katılımcılar üzerinde yapılan randomize kontrollü bir çalışmada, goji meyvelerinin yaşlı bireylerde yaygın bir göz hastalığı olan makular dejenerasyona karşı koruyucu etkiler sergilediği gösterilmiştir. Günlük olarak 90 gün boyunca $13.7 \mathrm{~g}$ lakto-wolfberry (LWB) (tescilli süt bazlı bir kurt üzümü formülasyonu) diyet takviyesi alan bireylerde, plazma antioksidan ve zeaksantin düzeylerinin sırasıyla \%26 ve \%57 oranında yükseldiği gözlemlenmiştir. ${ }^{41}$ Ayrıca, Goji ekstraktlarında bol miktarda bulunan ve esansiyel olmayan bir serbest amino asit olan taurinin, retina hücrelerinde yüksek CAMP seviyeleri ve artmış PPAR-y aktivitesi yoluyla diyabetik retinopatinin ilerlemesini engelleyebileceği de ileri sürülmektedir. ${ }^{42}$ cAMP seviyelerinin endotel bariyerinin işlev bozukluğuna karşı koruyucu olduğu bilinmektedir. ${ }^{[6]}$ Pavan ve ark., yüksek glikoz ile muamele edilmiş hücrelerde, yüksek CAMP konsantrasyonlarının epitelyal bariyerin bozulmasına aracılık ettiğini ve goji meyvelerinin bunların tersine çevrilmesini sağlamak için kullanılabileceğini göstermişlerdir. ${ }^{32}$

Goji meyveleri, zengin fitokimyasal ve antioksidan bileşimi nedeniyle uzun yıllardır kanserin oluşumunu ve ilerlemesini önlemek amacıyla geleneksel Çin tıbbında kullanılmaktadır. İçeriğindeki bazı bileşenler kanser gelişiminin engellenmesi üzerinde diğer gıdalardan daha iyi bir tedavi edici etki gösterebilmektedir. ${ }^{6,14} \mathrm{Bu}$ bağlamda, Hsu ve ark., goji meyvelerinden elde edilen karotenoidler ile hazırlanmış olan karotenoid nanoemülsiyonunun, karotenoid ekstraktına kıyasla HT-29 kanser hücrelerini inhibe etmede daha etkili olduğunu bildirmiştir. Ayrıca hem nanoemülsiyon hem de özüt, p53 ve p21 ekspresyonunu artırarak ve CDK1, $C D K 2$, siklin $A$ ve siklin $B$ ekspresyonunu ise azaltarak ve hücre döngüsünü $G 2 / M$ 'de durdurabildiği gösterilmiştir. ${ }^{43}$ Ayrıca, antikanser, antitümör ve immünomodülatör ve özellikler dahil olmak üzere meyvelerin biyolojik etkilerinin çoğuna atfedilen goji meyveleri, suda çözünür peptit konjuge polisakkaritler açısından da son derecede zengindir. ${ }^{29,44,45}$ Lycium meyvelerinin, konak organizmaya zarar vermeden tümör büyümesini engelleyecek şekilde konak savunma mekanizmalarını güçlendirme yeteneğine sahip olduğu ve içerdiği bileşikler sayesinde kanser hücrelerine karşı proapoptotik ve antiproliferatif aktiviteye sahip olduğu rapor edilmiştir. ${ }^{44,45}$

Kurt üzümünün nörolojik koruyucu etkiye sahip olduğu ve nörolojik performansı iyileştirdiği, insan klinik denemelerini de içeren deneysel çalışmalarda gösterilmiştir. Glutamatın eksitotoksik olduğu gösterilmiştir ve Parkinson hastalığı ve Alzheimer hastalığı dahil olmak üzere birçok nörodejeneratif hastalıkta rol oynamaktadır. Bu nedenle, glutamat toksisitesinin azaltılması, bu nörodejeneratif hastalıklar için terapötik bir strateji olarak kabul edilmektedir. ${ }^{47,48}$ Yang ve arkadaşları tarafından yapılan bir çalışmada, Lycium 
meyvelerinin felç modeli oluşturulan C57BL/6N erkek farelerde enfarktüs boyutunu, hemisferik şişmeyi ve su içeriğini azaltarak nörolojik defisitleri önemli ölçüde iyileştirdiği gösterilmiş ve bu nedenle goji meyvelerinin önemli bir nöroprotektif ajan olduğu öne sürlmüştür. ${ }^{23}$

Sıçanlarda iskemi/reperfüzyonda miyokardiyal hasarın azaltılmasında Lycium polisakkaritlerinin rolünü araştırmak için yapılan bir deneyde, goji polisakkaritlerinin doza bağımlı olarak sıçan kalbinde miyokard Baxpozitif oranını önemli ölçüde azalttığı; ayrıca miyokardiyal hücrenin apoptozunu ve Bcl-2 pozitif oranını artırdığı gösterilmiştir. Çalışma bulguları, Lycium polisakkaritlerinin kardiyovasküler hastalıklara karşı koruyucu role sahip olabileceğini düşündürmektedir. ${ }^{6}$ Lycium polisakkaritlerinin renal vasküler gerilim üzerindeki etkileri ile ilgili olarak, Jia ve ark., hipertansiyonlu sıçanlar arasında hipertansiyon modelini test etmişlerdir. Hipertansiyon tedavisi görmeyen sıçanlarla karşılaştırıldığında, goji polisakkaritleri ile tedavi edilen sıçanların izole aort halkalarında, azalmış fenilefrin kasılmasının gözlendiği ve bunun yüksek kan basıncının önemli ölçüde önlenmesine neden olduğu gözlenmiştir ${ }^{49}$. Bunun yanı sıra, Goji meyvelerin yüksek kan basıncını düşürücü etkilerinin yanı sıra; karaciğerde toplam kolesterol, trigliserit ve serum düşük yoğunluklu lipoprotein- (LDL-) C düzeylerinin azalmasına da katkı sağladığı ortaya konulmuştur. ${ }^{8,49}$

Hiperglisemi olarak da bilinen diabetes mellitus, anormal derecede yüksek kan şekeri seviyeleri ile karakterize bir hastalıktır. ${ }^{6,35,48}$ Yapılan hücre ve hayvan çalışmalarında fonksiyonel bir gıda olarak goji berry'nin hipoglisemik bir etkiye sahip olduğu ve glikoz alımı üzerinde konsantrasyona bağlı etki gösterdiği kanıtlanmıştır. ${ }^{46}$ Diyabetik sıçanlar ile yapılan bir çalışmada, kontrol grubuna kıyasla Lycium polisakkaritleri uygulanan grupta kan glukoz konsantrasyonlarının önemli ölçüde azaldığı tespit edilmiştir. ${ }^{35} 10$ gün boyunca goji meyvelerinden elde edilen ham ve saflaştırılmış polisakarit fraksiyonu ile beslenen, alloksan ile indüklenmiş diyabetik tavşanlarda da kan glukoz seviyesinde önemli oranda bir azalma olduğu gösterilmiştir. ${ }^{8}$

Son yıllarda yapılan çalışmalar, goji meyvelerinin içerdikleri polisakkaritler, betain, $\beta$-karoten, zeaksantin, 20- $\beta$-D-glukopiranozil-L-askorbik asit (AA-2 $\beta G$ ) ve flavanoidler sayesinde yaşlanma karşıtı oldukları ortaya konulmuştur. ${ }^{50}$ Bunun yanı sıra, betain (doğal bir amino asit) içeren Lycium meyve özütlerinin, antioksidatif aktiviteyi artırarak ve COX-1/COX-2 ve iNOS gibi enflamatuvar aracıları azaltarak karbon tetraklorür- $\left(\mathrm{CCl}_{4^{-}}\right)$ kaynaklı karaciğer hasarını hafiflettiği gösterilmiştir. ${ }^{30}$ Betainin, kolon karsinogenezi ile ilişkili bir antienflamasyon ajanı olduğu ve azoksimetan ile indüklenen farelerde kolit ile ilişkili kanser üzerinde tümör gelişimini önleyici bir etkiye sahip olduğu da gösterilmiştir. Ayrıca betain ile muamele edilen hücrelerde, betain inflamasyonun azalmasına katkı sağlayarak, tümör oluşumunun insidansını önemli ölçüde azaltmıştır. Betain ile tedavi kolon mukozasında ROS ve GSSG seviyesinin üretimini ve IL-6, iNOS, TNF- $\alpha$ ve COX-2 dahil olmak üzere inflamatuvar sitokinleri inhibe etmiştir. ${ }^{51}$ Betain, hücre dışı sinyalle düzenlenen kinazı (ERK), protein kinazı (MEK) ve matris metalloproteinaz 9 (MMP-9)'u inhibe ederek ultraviyole B ışınlarının neden olduğu kırışıkık ve kollajen hasarının oluşumunu baskılamak için kullanılmaktadır. ${ }^{6}$ Sahip olduğu zengin farmakolojik özelliklerinin yanı sıra, goji meyvelerinin ve meyvelerden elde edilen etken maddelerin, alerjik ve anafilaktik reaksiyonları engellediği de yapılan klinik çalışmalarla ortaya konulmuştur. ${ }^{52}$

\section{Sonuç ve Öneriler}

Geleneksel Çin tıbbında yüzlerce yıldan bu yana kullanılan goji meyveleri (Lycium), tıbbi özelliğe sahip önemli bir meyvedir. Tıbbi kullanımının yanı sıra, diyetin de önemli bir unsuru olarak kullanılmaktadır. Son zamanlarda, dünya genelinde kuru meyve, bitkisel çay, meyve suyu, tatı yapımı, müsli ve gıda takviyeleri olarak Lycium meyvelerinin kullanımına karşı artan bir ilgi söz konusudur. Serbest radikallerin DNA, lipit ve proteinlere zarar vermesini önleyerek, hücrelerde meydana gelen oksidatif stresi azaltmaya katkı sağlayan goji meyveleri; yüksek antioksidan potansiyeli ile karakterize edilen birçok biyoaktif bileşiğin kaynağıdır. Zengin fitokimyasal içerik ve geniş biyolojik aktivite yelpazesine sahip olan goji meyveleri; oksidatif stres kaynaklı hastalıkların tedavisinde ve insan sağlığının korunmasında ciddi bir potansiyele sahiptir. Hemopoez, 
antiradyasyon, kanser ve yaşlanmayı önleyici olan Lycium meyveleri aynı zamanda; bağışıklığın güçlendirilmesi ve antioksidasyonun arttırılmasında da etkilidir. Goji meyvelerinin ve ihtiva ettiği biyoaktif bileşenlerin ilaç etken maddesi olarak kullanımlarına yönelik modellemelerin, deneysel çalışmaların ve klinik faz çalışmalarının yapılarak, olası toksik etkilerinin ortaya konulması ve böylece önemli bir ilaç etken maddesinin tıp ve eczacılık alanına kazandırılması gerekmektedir.

\section{Bilgi}

Yazar finansal veya başka bir yolla herhangi bir çıkar çatışmasının olmadığını beyan eder.

\section{Kaynaklar}

1. Gezici S, Sekeroglu N. Current perspectives in the application of medicinal plants against cancer: novel therapeutic agents. AntiCancer Agents Med Chem 2019;19(1):101-11.

2. Ahamed A, et al. Molecular perspective and anticancer activity of medicinal plants. Saudi J Biol Sci 2020;27(2):666-75

3. Akhtar MF, et al. Anticancer natural medicines: An overview of cell signaling and other targets of anticancer phytochemicals. Eur J Pharmacol 2020;173488.

4. Gezici S, Sekeroglu N. Comparative biological analyses on kenger and kenger coffee as novel functional food products. J Food Sci Tech 2021;1-11.

5. Kulczyński B, Gramza-Michałowska A. Goji berry (Lycium barbarum): composition and health effects-a review. Polish J Food Nutr Sci 2016;66(2):67-76

6. Ma ZF, et al. Goji berries as a potential natural antioxidant medicine: An insight into their molecular mechanisms of action. Oxid Med Cell Longev 2019.

7. Qian D, et al. Systematic review of chemical constituents in the genus Lycium (Solanaceae). Molecules 2017;22(6):911.

8. Luo $Q$, et al. Hypoglycemic and hypolipidemic effects and antioxidant activity of fruit extracts from Lycium barbarum. Life Sci 2004;76(2):137-49.

9. Wang CC, et al. Isolation of carotenoids, flavonoids and polysaccharides from Lycium barbarum L. and evaluation of antioxidant activity. Food Chem 2010;120(1):184-92.

10. Amagase H, Farnsworth NR. A review of botanical characteristics, phytochemistry, clinical relevance in efficacy and safety of Lycium barbarum fruit (Goji). Food Res Int 2011;44(7):1702-17.

11. Cheng J, et al. evidence-based update on the pharmacological activities and possible molecular targets of Lycium barbarum polysaccharides. Drug Des Dev Ther 2015;9:33.

12. Wawruszak A, et al. Anticancer effect of ethanol Lycium barbarum (Goji berry) extract on human breast cancer T47D cell line. Nat Prod Res 2016;30(17):1993-6.

13. Manthey AL, Chiu K, So KF. Effects of Lycium barbarum on the Visual System. Int Rev Neurobiol 2017;135:1-27.

14. Chen D, et al. Chemical constituents from Lycium barbarum (Solanaceae) and their chemophenetic significance.Biochem Syst Ecol 2021;97:104292.

15. Donno D, et al. Goji berry fruit (Lycium spp.): antioxidant compound fingerprint and bioactivity evaluation. J Funct Foods 2015;18:1070-1085.

16. Shah, T., Bule, M., \& Niaz, K. Goji Berry (Lycium barbarum)-A Superfood. In Nonvitamin and Nonmineral Nutritional Supplements 2019;(pp. 257-264). Academic Press.

17. Wenli S, Shahrajabian MH, Qi C. Therapeutic roles of goji berry and ginseng in traditional Chinese.J Nutr Food Secur 2019;4(4):293-305.

18. Kwok SS, et al. A systematic review of potential therapeutic use of Lycium barbarum polysaccharides in disease. BioMed Res Int 2019;1-18.

19. Davis AP, et al. Comparative toxicogenomics database (CTD): update 2021. Nucleic Acids Res 2021;49(1):1138-43.

20. Hai-Yang G, et al. Therapeutic effects of Lycium barbarum polysaccharide (LBP) on mitomycin C (MMC)-induced myelosuppressive mice. J Exp Ther Oncol 2004;4(3).

21. Gong H, et al. Therapeutic effects of Lycium barbarum polysaccharide (LBP) on irradiation or chemotherapy-induced myelosuppressive mice. Cancer Biother Radiopharm 2005;20(2):155-62.

22. Li XM, Ma YL, Liu XJ. Effect of the Lycium barbarum polysaccharides on age-related oxidative stress in aged mice.J Ethnopharm 2007;111(3):504-11.

23. Yang $X$, et al. Lycium barbarum polysaccharides reduce intestinal ischemia/reperfusion injuries in rats. Chem Biol Interact 2013;204(3):166-72.

24. Masci A, et al. Lycium barbarum polysaccharides: Extraction, purification, structural characterisation and evidence about hypoglycaemic and hypolipidaemic effects. A review. Food Chem 2018;254:377-89. 
25. Wu DT, et al. Review of the structural characterization, quality evaluation, and industrial application of Lycium barbarum polysaccharides. Trends Food Sci Technol 2018;79:171-83.

26. Potterat O. Goji (Lycium barbarum and L. chinense): phytochemistry, pharmacology and safety in the perspective of traditional uses and recent popularity. Planta Medica 2010;76(01);7-19.

27. Kim HP, et al. Zeaxanthin dipalmitate from Lycium chinense has hepatoprotective activity. Res Commun Mol Pathol Pharmacol 1997;97(3):301-14.

28. Cui B, et al. Antitumour activity of Lycium chinensis polysaccharides in liver cancer rats. Int J Biol Macromol 2012;51(3):314-8.

29. Tang WM, et al. A review of the anticancer and immunomodulatory effects of Lycium barbarum fruit. Inflammopharmacology 2012;20(6):307-14.

30. Ahn M, et al. Hepatoprotective effects of Lycium chinense Miller fruit and its constituent betaine in $\mathrm{CCl}_{4}$-induced hepatic damage in rats. Acta Histochem 2014;116(6):1104-12.

31. Chen W, et al. Lycium barbarum polysaccharides prevent memory and neurogenesis impairments in scopolamine-treated rats. PLoS One 2014;9(2):e88076.

32. Pavan, B., Capuzzo, A., \& Forlani, G. High glucose-induced barrier impairment of human retinal pigment epithelium is ameliorated by treatment with Goji berry extracts through modulation of cAMP levels. Exp Eye Res 2014;120:50-4.

33. Yousaf T, et al. Phytochemical profiling and antiviral activity of Ajuga bracteosa, Ajuga parviflora, Berberis lycium and Citrus lemon against Hepatitis C Virus. Microb Pathog 2018;118:154-8.

34. Wang $Y$, et al. The assembly and antitumor activity of lycium barbarum polysaccharide-platinum-based conjugates. J Inorg Biochem 2020;205:111001.

35. Zhao XQ, et al. Lycium barbarum L. leaves ameliorate type 2 diabetes in rats by modulating metabolic profiles and gut microbiota composition. Biomed Pharmacother 2020;121:109559.

36. Fu YW, et al. Lycium barbarum polysaccharide-glycoprotein preventative treatment ameliorates aversive stimuli-induced depression. Neural Regen Res 2021;16(3):543.

37. Zheng $X$, et al. Protective effects of Lycium barbarum polysaccharide on ovariectomy-induced cognition reduction in aging mice. Int J Mol Med 2021;48(1):1-13.

38. Chu PH, et al. Effect of Lycium barbarum (wolfberry) polysaccharides on preserving retinal function after partial optic nerve transection. PLoS One 2013;8(12):e81339.

39. Zhu Y, et al. Lycium barbarum polysaccharides attenuates $\mathrm{N}$-methy-N-nitrosourea-induced photoreceptor cell apoptosis in rats through regulation of poly (ADP-ribose) polymerase and caspase expression. J Ethnopharmacol 2016;191:125-34.

40. $\mathrm{Yu} \mathrm{H}$, et al. Dietary wolfberry upregulates carotenoid metabolic genes and enhances mitochondrial biogenesis in the retina of db/db diabetic mice. Mol Nutr Food Res 2013;57(7):1158-69.

41. Bucheli P, et al. Goji berry effects on macular characteristics and plasma antioxidant levels. Optom Vis Sci 2011;88(2):257-62.

42. Song MK, et al. Lycium barbarum (Goji Berry) extracts and its taurine component inhibit PPAR- $\gamma$-dependent gene transcription in human retinal pigment epithelial cells: possible implications for diabetic retinopathy treatment. Biochem Pharmacol 2011;82(9):1209-18.

43. Hsu HJ, et al. Preparation of carotenoid extracts and nanoemulsions from Lycium barbarum L. and their effects on growth of HT29 colon cancer cells. Nanotech 2017;28(13):135103.

44. Ooi VE, Liu F. Immunomodulation and anti-cancer activity of polysaccharide-protein complexes. Curr Med Chem 2000;7(7):715.

45. Gan L, et al. Immunomodulation and antitumor activity by a polysaccharide-protein complex from Lycium barbarum. Int Immunopharmacol 2004;4(4):563-9.

46. Tang HL, et al. Biochemical analysis and hypoglycemic activity of a polysaccharide isolated from the fruit of Lycium barbarum L. Int J Biol Macromol 2015;77:235-42.

47. Ho YS, et al. Polysaccharides from wolfberry antagonizes glutamate excitotoxicity in rat cortical neurons. Cell Mol Neurobiol 2009;29(8):1233-44.

48. Jing L, et al. Evaluation of hypoglycemic activity of the polysaccharides extracted from Lycium barbarum. Afr J Tradit Complement Altern Med 2009;6(4).

49. Jia YX, et al. The effect of Lycium barbarum polysaccharide on vascular tension in two-kidney, one clip model of hypertension. Sheng Li Xue Bao Acta Physiologica Sinica 1998;50(3):309-14.

50. Gao Y, et al. Lycium barbarum: a traditional Chinese herb and a promising anti-aging agent. Aging Dis 2017;8(6):778.

51. Kim DH, et al. Anti-inflammatory effects of betaine on AOM/DSS-induced colon tumorigenesis in ICR male mice. Int J Oncol 2014;45(3):1250-16.

52. Ballarin SM, et al. Anaphylaxis associated with the ingestion of Goji berries (Lycium barbarum). J Investig Allergol Clin Immunol 2011;21(7):567-70. 